\title{
Post-Planting Fertilization as a Reforestation Aid on a Sulfurous, Semiarid Surface Mine
}

\author{
Roger F. Walker \\ Department of Natural Resources and Environmental Science, University of Nevada, Reno, USA. \\ Email: walker@cabnr.unr.edu.
}

Received February $12^{\text {th }}, 2013$; revised April 21 ${ }^{\text {st }}, 2013$; accepted May $6^{\text {th }}, 2013$

Copyright (C) 2013 Roger F. Walker. This is an open access article distributed under the Creative Commons Attribution License, which permits unrestricted use, distribution, and reproduction in any medium, provided the original work is properly cited.

\begin{abstract}
Selected fertilizer formulations were assessed for their capacity to enhance growth and nutrition of Jeffrey pine (Pinus jeffreyi Grev. \& Balf.) seedlings on an acidic and possibly toxic Sierran surface mine when applied three years after planting. In a study encompassing five growing seasons conducted on a semiarid, montane surface mine site on the eastern slope of the Sierra Nevada, seedling survival, dimensions, and volume measurements were coupled with foliar and soil analyses for macronutrients, micronutrients, and potentially phytotoxic metallic elements. Administered by broadcasting at four rates each, the formulations consisted of an organic amendment derived from municipal biosolids; a controlled release fertilizer containing urea, ammoniacal, and nitrate $\mathrm{N}$ sources; and two conventional fertilizers with one featuring urea as the predominant $\mathrm{N}$ form while the other delivered ammoniacal and nitrate forms. None of the formulations induced seedling mortality regardless of application rate, but the controlled release fertilizer and the conventional urea-based formulation were the most stimulatory overall, with intermediate rates of both proving most advantageous among those tested. Foliar analysis revealed that enhanced $\mathrm{N}$ and $\mathrm{P}$ nutrition, which was otherwise severely impacted by soil infertility, possibly along with that of $\mathrm{K}$, probably accounted for most of the growth stimulation by the amendments, but an accessory role may have been attributable to reduced concentrations of potentially phytotoxic metallic elements, principally $\mathrm{Mn}$ but possibly including $\mathrm{Fe}, \mathrm{Cu}$, and $\mathrm{Al}$, for which soil levels were all exceedingly elevated. With careful selection of formulation and application rate, post-planting broadcast fertilization can enhance growth and nutrition of Jeffrey pine on degraded substrates. These results provide a more complete understanding of the benefits that judicious fertilization can impart to young forest stands on surface mines and other harsh sites.
\end{abstract}

Keywords: Reforestation; Forest Restoration; Mine Reclamation; Forest Fertilization; Forest Nutrition; Soil Toxicity; Jeffrey Pine; Pinus jeffreyi

\section{Introduction}

Among the more prominent and enduring examples of forest restoration is the reestablishment of woody vegetation on sites disturbed by surface mining [1,2], which usually involves amelioration of the physical and/or chemical properties of the substrate in order to ensure the persistence of the new forest cover. Because infertility is a near universal characteristic of mine soils [3-5], application of nutrient amendments is often considered to be a necessary component of the reforestation process. Of overriding importance in the evaluation of fertilization as a reforestation aid on such sites is its effect on seedling survival, however, and there have been long-standing concerns in this regard $[3,6]$. This is especially so regarding applications of conventional amendments at planting, which can induce several maladies that may ultimately contribute to mortality. Among them, amendments applied directly to the rooting zone that do not meter nutrient release at a moderate pace can damage young root systems by salt toxicity [7], while those administered as top dressing tend to over stimulate competing herbaceous vegetation, particularly when the latter has been intentionally established as dense ground covers through seeding efforts incorporated into mixed plantings $[8,9]$. Whether applied to the rooting zone or through broadcasting, amendments with high $\mathrm{N}$ content can stimulate disproportionate shoot growth relative to that of the root systems [10], which can predispose newly planted seedlings to desiccation, especially on drier sites. Potentially, delaying fertilization until new plantations on mine sites are well established may largely allay the above concerns, but questions remain about how long to 
delay, the type and formulation of amendment to apply, and the most advantageous rate of application. A recent study documented a field trial in which the first fertilization of a pine plantation on a mine site in the western US was administered during the sapling stage [11], which completely eliminated impacts on survival regardless of whether a conventional, controlled release, or organic amendment was applied, but it is unclear if so long a delay is necessary in order to avoid such impact. Furthermore, because delaying the fertilization of plantations until establishment is certain restricts applications to the substrate surface in order to avoid disturbance and injury of seedling root systems, it is uncertain whether nutrients thus applied will penetrate to the rooting zone in sufficient quantity to induce enough added growth for the practice to prove worthwhile.

Although the primary purpose of fertilization is $\mathrm{u}-$ nquestionably to remedy nutrient deficiencies, infertility is not always the only chemical property of surface mine substrates that can hinder reforestation. Another common impediment is soil acidity, or more specifically, the toxicity that ensues from elevated soil solution concentrations of metallic elements as the result of increased acidity. Such phytotoxicities, most often involving Mn and Al but potentially other elements as well [3-5], have been documented to occur in humid regions such as the eastern USA [12-14] and northern and central Europe [15,16] along with those of drier climate such as the western USA [17-19]. Customarily, applications of agricultural lime have been viewed as the most expedient and expeditious remedy for these acidity-induced toxicities in humid zones [3,20-22], but in reforestation trials on drier sites, seedling mortality and stunting have resulted when this practice has been implemented at planting with amendment placement in the rooting zone $[23,24]$. However, it has also been documented that application of controlled release fertilizers at planting using this approach has some capacity to ameliorate such phytotoxicities [23-25]. If a similar response can be elicited by broadcast application of nutrient amendments to established seedlings on mined sites, this would constitute a valuable secondary benefit of this fertilization approach when applied to potentially toxic substrates.

Results presented here are derived from an investingation of the growth and nutritional responses of Jeffrey pine seedlings on sulfurous Sierran surface mine spoils to broadcast fertilization administered three years after planting. Organic, controlled release, and conventional formulations with multiple rates of application were examined. Foliar analysis focused on both essential nutriaents and potentially phytotoxic elements provided for a diagnostic interpretation of seedling reactions to treatment.

\section{Materials and Methods}

\subsection{Study Site and Soil Analysis}

An open-pit sulfur mine and spoil bank complex consisting of approximately 100 ha at an elevation of $2200 \mathrm{~m}$ in the eastern Sierra Nevada provided the study site $\left(38^{\circ} 42.50^{\prime} \mathrm{N}, 119^{\circ} 39.25^{\prime} \mathrm{W}\right)$. Annual precipitation averages $50 \mathrm{~cm}$ and is almost exclusively snowfall. The mine soil is derived from hydrothermally altered volcanic rock, primarily andesites, is predominantly porous silica with small amounts of montmorillonite clays, exhibits no obvious profile development, and the substratum contains considerable Fe pyrite [17]. The mine was operative from 1952 until 1962, and although continuously inactive since the latter year, is nearly devoid of vegetation except for scattered Jeffrey pine established as either natural recolonization or as small plantations of various ages. Second growth forest stands immediately adjacent to the mine complex, along with the sparse precipitation, elevation, aspect, and soil characteristics, indicate that this species was predominant in the vegetative cover existing prior to excavation [26].

The study was situated on a 0.8 ha level bench consisting of spoil materials excavated from the nearby pit. Prior to study installation, five soil subsamples were collected to a depth of $30 \mathrm{~cm}$ from each corner and from the center of the bench and combined into one composite sample per location for a total of five composite samples. These were air dried for 30 days, sieved to pass a No. 10 (2.0 mm opening) screen, and analyzed as follows: texture by the hydrometer method; organic matter by loss on ignition; $\mathrm{pH}$ by glass electrode on a 1:1 mixture (by weight) of soil and distilled water; total $\mathrm{N}$ by macro-Kjeldahl digestion; P (Bray 1) colorimetrically after extraction with $\mathrm{NH}_{4} \mathrm{~F}$ and $\mathrm{HCl} ; \mathrm{K}, \mathrm{Ca}, \mathrm{Mg}$, and $\mathrm{S}$ by inductively coupled plasma (ICP) spectroscopy after extraction with $\mathrm{NH}_{4} \mathrm{C}_{2} \mathrm{H}_{3} \mathrm{O}_{2} ; \mathrm{Fe}, \mathrm{Mn}, \mathrm{Zn}, \mathrm{Cu}$, and B by ICP spectroscopy after extraction with $\mathrm{HCl}$; and $\mathrm{Al}$ by ICP spectroscopy after extraction with $\mathrm{KCl}[27,28]$.

\subsection{Study Installation}

The study utilized a three-year-old Jeffrey pine plantation occupying the spoil bench indicated above. This plantation had been established by auger planting 2 - 0 bareroot seedlings derived from an appropriate seed source and produced by the USDA Forest Service Placerville Nursery (Camino, CA) through routine methods [29]. Plantation spacing was $2.0 \mathrm{~m}$ between rows and $1.0 \mathrm{~m}$ within rows. For treatment installation, 85 plots were delineated, each consisting of 10 consecutive seedlings within a plantation row, and one of 17 treatments was then assigned to each of five randomly chosen plots, thus creating a completely randomized experimental design. Treatments consisted of four fertilizer formulations with four 
application rates per formulation and an unfertilized control. The fertilizers were applied in mid April by surface broadcasting, without tillage into the soil, within a 0.5 -m-diameter circle centered at the seedling base. The formulations consisted of an organic 6-2-0 NPK fertilizer with $\mathrm{N}$ derived exclusively from municipal biosolids (MB); a controlled release 22-4-6 NPK fertilizer with urea, ammoniacal, and nitrate $\mathrm{N}$ sources plus an extensive array of micronutrients (CR); a conventional 29-3-4 NPK fertilizer featuring urea as the predominant $\mathrm{N}$ source along with a minor ammoniacal component (UR); and a conventional, water soluble 21-7-14 NPK fertilizer containing near equal ammoniacal and nitrate $\mathrm{N}$ sources (AN). Chemical specifications of each of the four formulations are detailed in Table 1. These fertilizers are representative of readily available soil amendments that differ in properties assumed to be crucial performance determinants, especially the featured $\mathrm{N}$ forms and the extent to which nutrient release is prolonged, with the latter factor partially dependent upon the former with respect to critical $\mathrm{N}$ nutrition. As reviewed by Tisdale et al. [30], municipal biosolid $\mathrm{N}$ is largely water insoluble and leaching losses are negligible, as are those of volatilization even with surface applications, but it must undergo extensive and sometimes protracted transformation to become plant available. In contrast, urea is water soluble and is subject to volatilization losses with surface applications, but it must also undergo transformation to provide plant available ions. Ammoniacal and nitrate $\mathrm{N}$ are water soluble and readily plant available but the latter is extremely susceptible to leaching loss. As for the duration of release, the organic $\mathrm{N}$ form in MB undoubtedly provides sustained delivery of this critical nutrient, a resin coating on the prills extends the release of all nutrients in CR to approximately three years with subsurface applications in Sierra Nevada soils [31], and polymer and S coating of one-third of the urea in UR prolongs the somewhat sustained $\mathrm{N}$ release inherent in this source. However, uncertainty surrounds the capacity of mine soils to promote the transformations to plant available $\mathrm{N}$ from both organic sources and urea at rates sufficient to provide worthwhile growth gains, especially with amendments applied to the soil surface. Essentially lacking altogether is a capacity of AN to moderate the release of any nutrient it supplies. The four application rates for MB were 100, 200, 300, and $400 \mathrm{~g}$ per seedling while those for CR, UR, and AN were 25, 50, 75, and $100 \mathrm{~g}$ per seedling.

\subsection{Survival and Growth Assessment}

To evaluate any treatment impacts on seedling mortality, survival was assessed in each of the 85 plots at the conclusions of the first and fifth posttreatment growing seasons. Initial measurements of seedling height and basal stem diameter were made at fertilization, and these dimensions were then remeasured following the first and fifth posttreatment seasons. Dimension measurements were subsequently used to calculate an estimate of shoot volume by the formula of Ruehle et al. [32]. For dimension measurements and volume estimates, relative growth was calculated after the first posttreatment season based on seedling size at fertilization (seasons 0 - 1) and after the fifth season based on that at the end of the first season (seasons $1-5$ ). These relative growth calculations provide a more accurate assessment of initial and long term growth responses, respectively, by accommodating differences in initial seedling size.

\subsection{Nutritional Analysis}

During the third week of July in the first posttreatment growing season, current-year needle subsamples were collected from the upper one-third crown of every seedling and combined into composite samples by plot, a foliar sampling protocol repeated verbatim in the fifth season. At collection, the needles were approximately $80 \%$ elongated. All samples were dried at $75^{\circ} \mathrm{C}$ for $24 \mathrm{hr}$, ground to pass a 20 -mesh $(850-\mu \mathrm{m}$ opening) screen, and then analyzed for total $\mathrm{N}$ using a Leco Model FP428 N Analyzer (Leco Corp., St. Joseph, MI) and for P, K, Ca, $\mathrm{Mg}, \mathrm{S}, \mathrm{Fe}, \mathrm{Mn}, \mathrm{Zn}, \mathrm{Cu}, \mathrm{B}$, and $\mathrm{Al}$ by ICP spectroscopy after wet ashing with $\mathrm{HNO}_{3}$ and $\mathrm{HClO}_{4}$ [33].

\subsection{Statistical Analysis}

Growth and nutritional data were subjected to repeated measures, mixed model analysis of variance (ANOVAR) incorporating the compound symmetry covariance structure. Effects of treatment and season, plus their interaction, were considered significant only when $P \leq 0.05$ according to the $\mathrm{F}$ test. Differences among means were evaluated using the least significant difference (LSD) test with $\alpha=0.05$. All statistical analyses were accomplished using the Statistical Analysis System (SAS Institute, Inc., Cary, NC). In the results that follow, $P$ values are included in the text when significant effects were revealed by ANOVAR, while the mean comparison analysis embodied in the LSD test was employed to appraise the performances of individual combinations of amendment formulation and application rate.

\section{Results}

\subsection{Soil Properties}

The analysis of the mine soil revealed the following properties: $67 \%$ sand, $22 \%$ silt, and $11 \%$ clay (sandy loam textural class); organic matter, $0.1 \%$; and $\mathrm{pH}, 4.7$. Elemental concentrations (in $\mu \mathrm{g} \cdot \mathrm{g}^{-1}$ ) were: total N, 619; P (Bray 1), 21; K, 252; Ca, 3403; Mg, 358; S, 223; Fe, 296; 
Table 1. Percent by weight of macronutrients and micronutrients provided by organic, controlled release, and conventional fertilizer formulations evaluated for their capacity to stimulate growth of Jeffrey pine seedlings on a Sierran surface mine.

\begin{tabular}{|c|c|c|c|c|}
\hline \multirow[b]{2}{*}{ Nutrient } & \multicolumn{3}{|c|}{ Fertilizer } & \multirow[b]{2}{*}{$\mathrm{AN}$} \\
\hline & MB & $\mathrm{CR}$ & UR & \\
\hline N (biosolid) & 6.0 & 0 & 0 & 0 \\
\hline $\mathrm{N}$ (urea) & 0 & 10.8 & 27.8 & 0 \\
\hline $\mathrm{N}$ (ammoniacal) & 0 & 5.9 & 1.2 & 11.0 \\
\hline $\mathrm{N}$ (nitrate) & 0 & 5.3 & 0 & 10.0 \\
\hline $\mathrm{P}\left(\mathrm{P}_{2} \mathrm{O}_{5}\right)$ & 2 & 4 & 3 & 7 \\
\hline $\mathrm{K}\left(\mathrm{K}_{2} \mathrm{O}\right)$ & 0 & 6 & 4 & 14 \\
\hline $\mathrm{Ca}$ & 0 & 1 & 0 & 0 \\
\hline $\mathrm{Mg}$ & 0 & 1 & 0 & 0 \\
\hline S & 0 & 3.0 & 3.9 & 5.0 \\
\hline $\mathrm{Fe}$ & 4 & 1 & 2 & 0 \\
\hline $\mathrm{Mn}$ & 0 & 0.1 & 0 & 0 \\
\hline $\mathrm{Zn}$ & 0 & 0.05 & 0 & 0 \\
\hline $\mathrm{Cu}$ & 0 & 0.05 & 0 & 0 \\
\hline B & 0 & 0.02 & 0 & 0 \\
\hline Mo & 0 & 0.001 & 0 & 0 \\
\hline
\end{tabular}

Mn, 99; Zn, 2.7; Cu, 19.5; B, 0.9; and Al, 236. Relative to undisturbed eastern Sierran forest soils supporting Jeffrey pine [34], this mine soil is more acidic and much lower in organic matter, $\mathrm{N}$, and $\mathrm{P}$ while higher in all other elements indicated above, with the disparities in $\mathrm{Mn}, \mathrm{Zn}, \mathrm{Cu}$, and $\mathrm{Al}$ especially pronounced regarding potentially phytotoxic metals. A previous soil assessment at this site [17] revealed that Al toxicity was a probable impediment to revegetation.

\subsection{Survival and Growth Responses}

Regardless of treatment, mortality was entirely absent among the seedlings incorporated into this study throughout its duration. All differences among treatments in seedling height, diameter, and volume were nonsignificant at the onset of the study according to the LSD test (Table 2).

ANOVAR revealed significant fertilization treatment $(P=0.046)$ and season $(P<0.001)$ influences on relative growth in height (Table 2). For seasons 0-1, the LSD test revealed that the $200 \mathrm{~g}$ rate of $\mathrm{MB}, 25 \mathrm{~g}$ and $50 \mathrm{~g}$ rates of $\mathrm{CR}$, and the $25 \mathrm{~g}$ rate of $\mathrm{AN}$ produced height growth responses exceeding that of the control, while the $50 \mathrm{~g}$, $75 \mathrm{~g}$, and $100 \mathrm{~g}$ rates of $\mathrm{CR}, 50 \mathrm{~g}$ and $75 \mathrm{~g}$ rates of UR, and $75 \mathrm{~g}$ and $100 \mathrm{~g}$ rates of AN did so in seasons $1-5$. All of the above disparities amounted to an approximate doubling of proportional growth in this dimension. The LSD test also revealed that seasons $0-1$ height growth in the $200 \mathrm{~g} \mathrm{MB}$ and $50 \mathrm{~g} \mathrm{CR}$ treatments, which exhibited the highest overall numerical values, exceeded that in the $50 \mathrm{~g}$ UR treatment while the seasons $1-5$ growth in the $75 \mathrm{~g} \mathrm{CR}$ and $50 \mathrm{~g}$ UR treatments, the highest numerical values for this period, was greater than that in the $200 \mathrm{~g}$ $\mathrm{MB}$ and $25 \mathrm{~g}$ UR treatments. Proportional height growth for seasons $1-5$ exceeded the growth for seasons $0-1$ by a factor exceeding that representing the difference in the length of the two periods for all treatments, with disparities that were especially pronounced for the $75 \mathrm{~g} \mathrm{CR}$ and $50 \mathrm{~g}$ UR treatments.

For relative growth in basal diameter, ANOVAR again indicated significant treatment $(P=0.048)$ and season $(P$ $<0.001$ ) effects (Table 2). However, the LSD test revealed that significant differences among treatments for seasons $0-1$ were limited to higher values in the $50 \mathrm{~g}$ $\mathrm{CR}$ and $75 \mathrm{~g}$ AN treatments than that for the control. Nevertheless, such differences were more prevalent in seasons $1-5$, as growth in the $25 \mathrm{~g}, 75 \mathrm{~g}$, and $100 \mathrm{~g} \mathrm{CR}$ treatments and the $50 \mathrm{~g}, 75 \mathrm{~g}$, and $100 \mathrm{~g}$ UR and AN treatments all exceeded that of the control, with all of these disparities amounting to an approximate doubling of proportional growth. For seasons 1-5, the LSD test also indicated greater growth in the $50 \mathrm{~g}$ UR and $75 \mathrm{~g}$ and $100 \mathrm{~g} \mathrm{CR}$ treatments, which exhibited the highest numerical values overall, than in the $200 \mathrm{~g} \mathrm{MB}$ treatment. The disparities in proportional diameter growth between seasons $0-1$ and seasons $1-5$ were less pronounced overall than those indicated above for height, with that exhibited by the $100 \mathrm{~g} \mathrm{CR}$ treatment marginally superior to the other treatments.

With ANOVAR again indicating significant treatment $(P=0.048)$ and season $(P<0.001)$ influences with regards to relative growth in seedling volume, the LSD test also revealed numerous differences among treatments in volume growth entailing comparisons with the control as well as among fertilized seedlings (Table 2). Specifically, the $400 \mathrm{~g} \mathrm{MB}, 50 \mathrm{~g} \mathrm{CR}$, and $75 \mathrm{~g} \mathrm{AN}$ treatments induced increases exceeding that of the control in seasons $0-1$ while the $25 \mathrm{~g}, 75 \mathrm{~g}$, and $100 \mathrm{~g} \mathrm{CR}$ treatments along with the $50 \mathrm{~g}$ and $75 \mathrm{~g}$ UR treatments did so in seasons $1-5$. For seasons $0-1$ and seasons $1-5$, the above disparities represent an approximate doubling and tripling, respectively, of growth rates. Additional differences identified by the LSD test were greater growth in the $50 \mathrm{~g} \mathrm{CR}$ treatment, which exhibited the highest overall numerical value, than in either the $50 \mathrm{~g}$ or $100 \mathrm{~g}$ AN treatment for seasons $0-1$, and for seasons $1-5$, greater growth in the $75 \mathrm{~g} \mathrm{CR}$ and $50 \mathrm{~g}$ UR treatments, the highest numerical values for this period, than in either the $200 \mathrm{~g}$ MB or 25 
Table 2. Initial dimensions and growth stimulation by organic, controlled release, and conventional fertilizers of Jeffrey pine seedlings on a Sierran surface mine ${ }^{\mathrm{a}}$.

\begin{tabular}{|c|c|c|c|c|c|c|c|c|c|}
\hline \multirow[b]{3}{*}{ Treatment } & \multicolumn{3}{|c|}{ Height } & \multicolumn{3}{|c|}{ Diameter } & \multicolumn{3}{|c|}{ Volume } \\
\hline & \multirow[b]{2}{*}{$\begin{array}{c}\text { Initial } \\
(\mathrm{cm})\end{array}$} & \multicolumn{2}{|c|}{ Relative growth $^{\mathrm{b}}$} & \multirow[b]{2}{*}{$\begin{array}{c}\text { Initial } \\
(\mathbf{m m})\end{array}$} & \multicolumn{2}{|c|}{ Relative growth $^{\mathrm{b}}$} & \multirow[b]{2}{*}{$\begin{array}{l}\text { Initial } \\
\left(\mathrm{cm}^{3}\right)\end{array}$} & \multicolumn{2}{|c|}{ Relative growth ${ }^{\mathrm{b}}$} \\
\hline & & $\begin{array}{c}\text { Seasons } \\
0-1\end{array}$ & $\begin{array}{c}\text { Seasons } \\
1-5\end{array}$ & & $\begin{array}{c}\text { Seasons } \\
0-1\end{array}$ & $\begin{array}{c}\text { Seasons } \\
1-5\end{array}$ & & $\begin{array}{c}\text { Seasons } \\
0-1\end{array}$ & $\begin{array}{c}\text { Seasons } \\
1-5 \\
\end{array}$ \\
\hline \multicolumn{10}{|l|}{ MB } \\
\hline $100 \mathrm{~g}$ & $24.0 \mathrm{a}$ & $0.15 \mathrm{abc}$ & $1.13 \mathrm{abc}$ & $10.7 \mathrm{a}$ & $0.25 \mathrm{ab}$ & $1.08 \mathrm{abc}$ & $34.3 \mathrm{a}$ & $0.88 \mathrm{abc}$ & $10.29 \mathrm{abc}$ \\
\hline $200 \mathrm{~g}$ & $25.4 \mathrm{a}$ & $0.21 \mathrm{a}$ & $0.87 \mathrm{bc}$ & $11.2 \mathrm{a}$ & $0.23 \mathrm{ab}$ & $0.78 \mathrm{bc}$ & $38.4 \mathrm{a}$ & $0.94 \mathrm{abc}$ & $6.63 \mathrm{bc}$ \\
\hline $300 \mathrm{~g}$ & $25.7 \mathrm{a}$ & $0.15 \mathrm{abc}$ & $1.15 \mathrm{abc}$ & $11.6 \mathrm{a}$ & $0.24 \mathrm{ab}$ & $0.95 \mathrm{abc}$ & $45.0 \mathrm{a}$ & $0.84 \mathrm{abc}$ & $9.21 \mathrm{abc}$ \\
\hline $400 \mathrm{~g}$ & $24.7 \mathrm{a}$ & $0.16 a b c$ & $1.15 \mathrm{abc}$ & $10.9 \mathrm{a}$ & $0.26 \mathrm{ab}$ & $1.00 \mathrm{abc}$ & $36.4 \mathrm{a}$ & $0.98 \mathrm{ab}$ & $12.35 \mathrm{abc}$ \\
\hline \multicolumn{10}{|l|}{$\mathrm{CR}$} \\
\hline $25 \mathrm{~g}$ & $24.6 \mathrm{a}$ & $0.17 \mathrm{ab}$ & $1.13 \mathrm{abc}$ & $11.4 \mathrm{a}$ & $0.24 \mathrm{ab}$ & $1.18 \mathrm{ab}$ & $43.1 \mathrm{a}$ & $0.91 \mathrm{abc}$ & $13.18 \mathrm{ab}$ \\
\hline $50 \mathrm{~g}$ & $24.4 \mathrm{a}$ & $0.23 \mathrm{a}$ & $1.39 \mathrm{ab}$ & $11.4 \mathrm{a}$ & $0.29 \mathrm{a}$ & $1.08 \mathrm{abc}$ & $39.9 \mathrm{a}$ & $1.14 \mathrm{a}$ & $11.28 \mathrm{abc}$ \\
\hline $75 \mathrm{~g}$ & $24.1 \mathrm{a}$ & $0.14 \mathrm{abc}$ & $1.62 \mathrm{a}$ & $11.2 \mathrm{a}$ & $0.25 \mathrm{ab}$ & $1.37 \mathrm{a}$ & $38.1 \mathrm{a}$ & $0.84 \mathrm{abc}$ & $17.75 \mathrm{a}$ \\
\hline $100 \mathrm{~g}$ & $24.2 \mathrm{a}$ & $0.16 \mathrm{abc}$ & $1.35 \mathrm{ab}$ & $10.8 \mathrm{a}$ & $0.22 \mathrm{ab}$ & $1.34 \mathrm{a}$ & $35.7 \mathrm{a}$ & $0.79 \mathrm{abc}$ & $14.98 \mathrm{ab}$ \\
\hline \multicolumn{10}{|l|}{ UR } \\
\hline $25 \mathrm{~g}$ & $25.8 \mathrm{a}$ & $0.16 \mathrm{abc}$ & $0.86 \mathrm{bc}$ & $11.3 \mathrm{a}$ & $0.21 \mathrm{ab}$ & $1.02 \mathrm{abc}$ & $44.1 \mathrm{a}$ & $0.80 \mathrm{abc}$ & $7.93 b c$ \\
\hline $50 \mathrm{~g}$ & $24.2 \mathrm{a}$ & $0.13 b c$ & $1.68 \mathrm{a}$ & $11.1 \mathrm{a}$ & $0.26 \mathrm{ab}$ & $1.44 \mathrm{a}$ & $37.8 \mathrm{a}$ & $0.90 \mathrm{abc}$ & $17.79 \mathrm{a}$ \\
\hline $75 \mathrm{~g}$ & $24.5 \mathrm{a}$ & $0.14 \mathrm{abc}$ & $1.44 \mathrm{ab}$ & $10.8 \mathrm{a}$ & $0.27 \mathrm{ab}$ & $1.19 \mathrm{ab}$ & $35.6 \mathrm{a}$ & $0.96 \mathrm{abc}$ & 13.39ab \\
\hline $100 \mathrm{~g}$ & $24.8 \mathrm{a}$ & $0.16 a b c$ & $1.15 \mathrm{abc}$ & $11.2 \mathrm{a}$ & $0.23 \mathrm{ab}$ & $1.23 \mathrm{ab}$ & $34.7 \mathrm{a}$ & $0.86 \mathrm{abc}$ & $11.47 \mathrm{abc}$ \\
\hline \multicolumn{10}{|l|}{ AN } \\
\hline $25 \mathrm{~g}$ & $24.3 \mathrm{a}$ & $0.18 \mathrm{ab}$ & $0.99 \mathrm{abc}$ & $10.9 \mathrm{a}$ & $0.25 \mathrm{ab}$ & $1.04 \mathrm{abc}$ & $38.6 \mathrm{a}$ & $0.96 a b c$ & $8.48 \mathrm{abc}$ \\
\hline $50 \mathrm{~g}$ & $25.0 \mathrm{a}$ & $0.15 \mathrm{abc}$ & $1.15 \mathrm{abc}$ & $11.5 \mathrm{a}$ & $0.21 \mathrm{ab}$ & $1.20 \mathrm{ab}$ & $42.8 \mathrm{a}$ & $0.76 \mathrm{bc}$ & $11.80 \mathrm{abc}$ \\
\hline $75 \mathrm{~g}$ & $24.9 \mathrm{a}$ & $0.16 a b c$ & $1.29 \mathrm{ab}$ & $11.2 \mathrm{a}$ & $0.28 \mathrm{a}$ & $1.25 \mathrm{ab}$ & $40.4 \mathrm{a}$ & $0.98 \mathrm{ab}$ & $12.83 \mathrm{abc}$ \\
\hline $100 \mathrm{~g}$ & $24.6 \mathrm{a}$ & $0.14 \mathrm{abc}$ & $1.30 \mathrm{ab}$ & $11.1 \mathrm{a}$ & $0.21 \mathrm{ab}$ & $1.19 \mathrm{ab}$ & $38.0 \mathrm{a}$ & $0.72 b c$ & $11.43 \mathrm{abc}$ \\
\hline Control & $24.7 \mathrm{a}$ & $0.09 \mathrm{c}$ & $0.71 \mathrm{c}$ & $11.1 \mathrm{a}$ & $0.18 b$ & $0.65 \mathrm{c}$ & $39.1 \mathrm{a}$ & $0.57 \mathrm{c}$ & $5.25 \mathrm{c}$ \\
\hline
\end{tabular}

${ }^{\mathrm{a}}$ Within each growth variable and time of measurement, means sharing a letter do not differ significantly at $\alpha=0.05$, and $\mathrm{n}=5 \mathrm{for}$ each combination of formulation and application rate. ${ }^{b}$ Relative growth was calculated as the proportion increase in seedling size during the indicated period.

g UR treatment. Proportional volume growth for seasons $1-5$ exceeded the growth for seasons $0-1$ by a factor well exceeding that representing the difference in period length regardless of treatment, but as was the case for the height dimension, the disparities were especially pronounced for the $75 \mathrm{~g} \mathrm{CR}$ and $50 \mathrm{~g}$ UR treatments.

\subsection{Nutritional Responses}

Regarding macronutrients, ANOVAR revealed that foliar concentrations of N $(P=0.042), \mathrm{P}(P=0.033), \mathrm{K}(P=$ $0.011), \mathrm{Ca}(P=0.046)$, and $\mathrm{S}(P=0.015)$ were influenced by treatment while those of $\mathrm{N}, \mathrm{P}, \mathrm{K}$, and $\mathrm{Mg}$ (all $P$ $<0.001$ ) were influenced by season (Table 3). For N, the LSD test indicated that the $400 \mathrm{~g} \mathrm{MB}, 75 \mathrm{~g}$ and $100 \mathrm{~g} \mathrm{CR}$, the $50 \mathrm{~g}, 75 \mathrm{~g}$, and $100 \mathrm{~g} \mathrm{UR}$, and all AN treatments produced concentrations exceeding the control during the first posttreatment season, while in the fifth season the control concentration was surpassed by that of all of the other treatments. The remaining disparities in foliar $\mathrm{N}$ identified by the LSD test consisted of a higher concentration in the $75 \mathrm{~g} \mathrm{CR}$ treatment than in either the $100 \mathrm{~g}$ or $200 \mathrm{~g} \mathrm{MB}$ treatment during the first season, and for the fifth season, higher concentrations in the $300 \mathrm{~g} \mathrm{MB}$, $75 \mathrm{~g}$ and $100 \mathrm{~g} \mathrm{CR}, 50 \mathrm{~g} \mathrm{UR}$, and $100 \mathrm{~g}$ AN treatments than in the $100 \mathrm{~g} \mathrm{MB}$ and UR treatments or the $25 \mathrm{~g}$ AN treatment. In the first season, foliar P in the control was exceeded by that in all other treatments, while in the fifth season it was exceeded by all except that in the $200 \mathrm{~g}$ $\mathrm{MB}, 25 \mathrm{~g}$ and $50 \mathrm{~g} \mathrm{CR}, 25 \mathrm{~g}$ and $100 \mathrm{~g} \mathrm{UR}$, and $50 \mathrm{~g}$ AN treatments. Other differences among treatments for $\mathrm{P}$ consisted of higher concentrations in the $300 \mathrm{~g} \mathrm{MB}$, the 
$50 \mathrm{~g}, 75 \mathrm{~g}$, and $100 \mathrm{~g} \mathrm{UR}$, and the $100 \mathrm{~g} \mathrm{AN}$ treatments than those in the $100 \mathrm{~g}$ and $200 \mathrm{~g}$ MB treatments during the first season along with concentrations in the $400 \mathrm{~g}$ $\mathrm{MB}, 75 \mathrm{~g} \mathrm{CR}, 50 \mathrm{~g}$ and $75 \mathrm{~g} \mathrm{UR}$, and $100 \mathrm{~g}$ AN treatments that were greater than those in the $50 \mathrm{~g}$ CR or $25 \mathrm{~g}$ UR treatments during the fifth season. The foliar K concentration in the control was also exceeded by that in all remaining treatments during the first season, but in the fifth season, it was exceeded by the $75 \mathrm{~g} \mathrm{CR}, 50 \mathrm{~g} \mathrm{UR}$, and $75 \mathrm{~g}$ AN treatments only. The remainder of the significant differences for $\mathrm{K}$ consisted of higher concentrations in the $75 \mathrm{~g} \mathrm{CR}$ and UR treatments than in the $200 \mathrm{~g}$ and $300 \mathrm{~g} \mathrm{MB}$ and the $25 \mathrm{~g}$ UR and AN treatments during the former plus a higher one in the $50 \mathrm{~g}$ than in the $100 \mathrm{~g}$ UR treatment during the latter. For N, P, and K, concentrations declined from the first to the fifth season within every combination of formulation and application rate.

In a departure from the three macronutrients noted above, $\mathrm{Ca}$ and $\mathrm{S}$ concentrations were often higher in the control than in several of the remaining treatments either in the first of fifth seasons or both (Table 3). Specifically, the control Ca concentration exceeded those in the $50 \mathrm{~g}, 75 \mathrm{~g}$, and $100 \mathrm{~g} \mathrm{CR}$ treatments, the $50 \mathrm{~g}$ and $75 \mathrm{~g}$ UR treatments, and the $75 \mathrm{~g} \mathrm{AN}$ treatment during the first season and exceeded those in the $75 \mathrm{~g} \mathrm{CR}$ and $50 \mathrm{~g}$ UR treatments during the fifth season according to the LSD test. Similarly, the control S concentration exceeded those in all remaining treatments except for the $200 \mathrm{~g}$ and $300 \mathrm{~g}$ MB treatments during the former and exceeded those in all except the $25 \mathrm{~g}, 75 \mathrm{~g}$, and $100 \mathrm{~g}$ UR treatments and the $50 \mathrm{~g}$ and $100 \mathrm{~g} \mathrm{AN}$ treatments during the latter. Other disparities revealed by the LSD test for Ca consisted of a higher concentration in the $200 \mathrm{~g}$ MB treatment than in the $50 \mathrm{~g} \mathrm{CR}$ and $75 \mathrm{UR}$ treatments during the first season, while for S they consisted of a higher one in the $200 \mathrm{~g}$ MB treatment than in the $50 \mathrm{~g} \mathrm{CR}$ and $75 \mathrm{~g} \mathrm{UR}$ and AN treatments for the first season along with higher ones in the $25 \mathrm{~g}$ UR and $100 \mathrm{~g}$ AN treatments than in the $75 \mathrm{~g}$ $\mathrm{CR}$ treatment during the fifth season. As proved true for $\mathrm{N}, \mathrm{P}$, and $\mathrm{K}, \mathrm{Mg}$ concentrations declined from the first to the fifth season within every treatment.

Regarding micronutrients, concentrations of $\mathrm{Fe}(P=$

Table 3. Concentrations of nutrients and Al in Jeffrey pine seedling foliage during the first (a) and fifth (b) posttreatment seasons as influenced by organic, controlled release, and conventional fertilizers applied to a Sierran surface mine ${ }^{\mathrm{a}}$.

(a)

\begin{tabular}{|c|c|c|c|c|c|c|c|c|c|c|c|c|}
\hline \multirow[b]{2}{*}{ Treatment } & \multicolumn{6}{|c|}{ Macronutrient concentration (\%) } & \multicolumn{5}{|c|}{ Micronutrient concentration $\left(\mu \mathrm{g} \cdot \mathrm{g}^{-1}\right)$} & \multirow{2}{*}{$\begin{array}{c}\text { Al } \\
\left(\mu \mathrm{g} \cdot \mathrm{g}^{-1}\right)\end{array}$} \\
\hline & $\mathbf{N}$ & $\mathbf{P}$ & $\mathbf{K}$ & $\mathbf{C a}$ & Mg & $\mathbf{S}$ & $\mathrm{Fe}$ & Mn & $\mathbf{Z n}$ & $\mathrm{Cu}$ & B & \\
\hline \multicolumn{13}{|l|}{ MB } \\
\hline $100 \mathrm{~g}$ & $1.07 \mathrm{bc}$ & $0.17 \mathrm{~b}$ & $1.19 \mathrm{ab}$ & $0.26 \mathrm{abc}$ & $0.12 \mathrm{a}$ & $0.18 b c$ & $101 b$ & $636 a b c$ & $34 \mathrm{a}$ & $7.4 \mathrm{~b}$ & $48 \mathrm{a}$ & $284 \mathrm{ab}$ \\
\hline $200 \mathrm{~g}$ & $1.09 \mathrm{bc}$ & $0.17 \mathrm{~b}$ & $1.17 \mathrm{~b}$ & $0.30 \mathrm{ab}$ & $0.13 \mathrm{a}$ & $0.27 \mathrm{ab}$ & $117 \mathrm{~b}$ & $756 \mathrm{abc}$ & $44 \mathrm{a}$ & $7.2 \mathrm{~b}$ & $57 \mathrm{a}$ & $353 \mathrm{ab}$ \\
\hline $300 \mathrm{~g}$ & $1.17 \mathrm{abc}$ & $0.20 \mathrm{a}$ & $1.18 \mathrm{~b}$ & $0.29 \mathrm{abc}$ & $0.11 \mathrm{a}$ & $0.23 \mathrm{abc}$ & $96 b$ & $975 \mathrm{ab}$ & $43 \mathrm{a}$ & $8.4 \mathrm{ab}$ & $84 a$ & $360 \mathrm{ab}$ \\
\hline $400 \mathrm{~g}$ & $1.29 \mathrm{ab}$ & $0.19 \mathrm{ab}$ & $1.19 \mathrm{ab}$ & $0.25 \mathrm{abc}$ & $0.12 \mathrm{a}$ & $0.22 \mathrm{bc}$ & $98 b$ & $647 \mathrm{abc}$ & $46 a$ & $8.0 \mathrm{ab}$ & $82 a$ & $386 a b$ \\
\hline \multicolumn{13}{|l|}{$\mathrm{CR}$} \\
\hline $25 \mathrm{~g}$ & $1.23 \mathrm{abc}$ & $0.18 \mathrm{ab}$ & $1.19 \mathrm{ab}$ & $0.26 \mathrm{abc}$ & $0.11 \mathrm{a}$ & $0.20 \mathrm{bc}$ & $82 b$ & $711 \mathrm{abc}$ & $42 a$ & $9.6 \mathrm{ab}$ & $49 a$ & $264 \mathrm{ab}$ \\
\hline $50 \mathrm{~g}$ & $1.22 \mathrm{abc}$ & $0.19 \mathrm{ab}$ & $1.23 \mathrm{ab}$ & $0.22 \mathrm{c}$ & $0.12 \mathrm{a}$ & $0.17 \mathrm{c}$ & $76 \mathrm{~b}$ & $567 \mathrm{bc}$ & $39 a$ & $7.0 \mathrm{~b}$ & $55 \mathrm{a}$ & $252 b$ \\
\hline $75 \mathrm{~g}$ & $1.34 \mathrm{a}$ & $0.19 \mathrm{ab}$ & $1.33 \mathrm{a}$ & $0.23 b c$ & $0.13 \mathrm{a}$ & $0.22 b c$ & $82 b$ & $578 b c$ & $43 a$ & $8.6 \mathrm{ab}$ & $60 a$ & $345 \mathrm{ab}$ \\
\hline $100 \mathrm{~g}$ & $1.26 \mathrm{ab}$ & $0.19 \mathrm{ab}$ & $1.22 \mathrm{ab}$ & $0.23 \mathrm{bc}$ & $0.13 \mathrm{a}$ & $0.20 \mathrm{bc}$ & $91 \mathrm{~b}$ & $631 \mathrm{abc}$ & $38 \mathrm{a}$ & $9.8 \mathrm{ab}$ & $47 a$ & $307 \mathrm{ab}$ \\
\hline \multicolumn{13}{|l|}{ UR } \\
\hline $25 \mathrm{~g}$ & $1.22 \mathrm{abc}$ & $0.19 \mathrm{ab}$ & $1.17 \mathrm{~b}$ & $0.27 \mathrm{abc}$ & $0.12 \mathrm{a}$ & $0.20 \mathrm{bc}$ & $130 \mathrm{~b}$ & $731 \mathrm{abc}$ & $46 a$ & $9.8 \mathrm{ab}$ & $62 a$ & $408 \mathrm{ab}$ \\
\hline $50 \mathrm{~g}$ & $1.27 \mathrm{ab}$ & $0.20 \mathrm{a}$ & $1.28 \mathrm{ab}$ & $0.23 b c$ & $0.13 \mathrm{a}$ & $0.21 b c$ & $91 b$ & $472 \mathrm{c}$ & $40 \mathrm{a}$ & $9.4 a b$ & $60 \mathrm{a}$ & $294 \mathrm{ab}$ \\
\hline $75 \mathrm{~g}$ & $1.27 \mathrm{ab}$ & $0.20 \mathrm{a}$ & $1.32 \mathrm{a}$ & $0.21 \mathrm{c}$ & $0.11 \mathrm{a}$ & $0.17 \mathrm{c}$ & $87 b$ & $618 b c$ & $35 \mathrm{a}$ & $9.9 \mathrm{ab}$ & $47 a$ & $273 \mathrm{ab}$ \\
\hline $100 \mathrm{~g}$ & $1.26 \mathrm{ab}$ & $0.20 \mathrm{a}$ & $1.27 \mathrm{ab}$ & $0.26 \mathrm{abc}$ & $0.13 \mathrm{a}$ & $0.20 \mathrm{bc}$ & $74 \mathrm{~b}$ & $628 \mathrm{abc}$ & $39 a$ & $9.6 \mathrm{ab}$ & $47 a$ & $287 \mathrm{ab}$ \\
\hline \multicolumn{13}{|l|}{ AN } \\
\hline $25 \mathrm{~g}$ & $1.26 \mathrm{ab}$ & $0.18 \mathrm{ab}$ & $1.18 \mathrm{~b}$ & $0.26 \mathrm{abc}$ & $0.12 \mathrm{a}$ & $0.20 \mathrm{bc}$ & $148 b$ & $821 \mathrm{ab}$ & $42 a$ & $7.8 \mathrm{ab}$ & $56 \mathrm{a}$ & $272 \mathrm{ab}$ \\
\hline $50 \mathrm{~g}$ & $1.25 \mathrm{ab}$ & $0.18 \mathrm{ab}$ & $1.22 \mathrm{ab}$ & $0.28 \mathrm{abc}$ & $0.12 \mathrm{a}$ & $0.19 b c$ & $85 b$ & $787 a b c$ & $41 \mathrm{a}$ & $9.6 \mathrm{ab}$ & $55 \mathrm{a}$ & $322 \mathrm{ab}$ \\
\hline $75 \mathrm{~g}$ & $1.26 \mathrm{ab}$ & $0.19 \mathrm{ab}$ & $1.24 \mathrm{ab}$ & $0.23 \mathrm{bc}$ & $0.11 \mathrm{a}$ & $0.17 \mathrm{c}$ & $95 \mathrm{~b}$ & 706abc & $41 \mathrm{a}$ & $8.2 \mathrm{ab}$ & $57 \mathrm{a}$ & $325 \mathrm{ab}$ \\
\hline $100 \mathrm{~g}$ & $1.30 \mathrm{ab}$ & $0.20 \mathrm{a}$ & $1.25 \mathrm{ab}$ & $0.26 \mathrm{abc}$ & $0.12 \mathrm{a}$ & $0.20 \mathrm{bc}$ & $68 \mathrm{~b}$ & $642 \mathrm{abc}$ & $42 a$ & $8.6 \mathrm{ab}$ & $51 \mathrm{a}$ & $261 \mathrm{ab}$ \\
\hline Control & $0.99 \mathrm{c}$ & $0.13 \mathrm{c}$ & $0.99 \mathrm{c}$ & $0.33 \mathrm{a}$ & $0.13 \mathrm{a}$ & $0.32 \mathrm{a}$ & $275 a$ & $1150 \mathrm{a}$ & $40 \mathrm{a}$ & $10.8 \mathrm{a}$ & $55 \mathrm{a}$ & $486 \mathrm{a}$ \\
\hline
\end{tabular}


(b)

\begin{tabular}{|c|c|c|c|c|c|c|c|c|c|c|c|c|}
\hline \multirow[b]{2}{*}{ Treatment } & \multicolumn{6}{|c|}{ Macronutrient concentration (\%) } & \multicolumn{5}{|c|}{ Micronutrient concentration $\left(\mu \mathrm{g} \cdot \mathrm{g}^{-1}\right)$} & \multirow{2}{*}{$\begin{array}{c}\text { Al } \\
\left(\mu \mathrm{g} \cdot \mathrm{g}^{-1}\right)\end{array}$} \\
\hline & $\mathbf{N}$ & $\mathbf{P}$ & $\mathbf{K}$ & $\mathrm{Ca}$ & Mg & $\mathbf{S}$ & $\mathbf{F e}$ & Mn & $\mathbf{Z n}$ & $\mathbf{C u}$ & B & \\
\hline \multicolumn{13}{|l|}{ MB } \\
\hline $100 \mathrm{~g}$ & $1.04 \mathrm{~b}$ & $0.14 \mathrm{ab}$ & $0.86 \mathrm{abc}$ & $0.26 \mathrm{ab}$ & $0.09 \mathrm{a}$ & $0.21 \mathrm{bc}$ & $146 \mathrm{ab}$ & $1005 \mathrm{ab}$ & $34 \mathrm{a}$ & $6.2 \mathrm{ab}$ & $60 \mathrm{a}$ & $147 \mathrm{ab}$ \\
\hline $200 \mathrm{~g}$ & $1.08 \mathrm{ab}$ & $0.13 \mathrm{abc}$ & $0.87 \mathrm{abc}$ & $0.30 \mathrm{ab}$ & $0.10 \mathrm{a}$ & $0.21 \mathrm{bc}$ & $165 \mathrm{ab}$ & $993 \mathrm{ab}$ & $40 \mathrm{a}$ & $4.2 \mathrm{ab}$ & $64 \mathrm{a}$ & $160 \mathrm{ab}$ \\
\hline $300 \mathrm{~g}$ & $1.13 \mathrm{a}$ & $0.14 \mathrm{ab}$ & $0.88 \mathrm{abc}$ & $0.25 \mathrm{ab}$ & $0.08 \mathrm{a}$ & $0.21 b c$ & $153 \mathrm{ab}$ & $910 \mathrm{ab}$ & $37 \mathrm{a}$ & $5.2 \mathrm{ab}$ & $60 \mathrm{a}$ & $155 \mathrm{ab}$ \\
\hline $400 \mathrm{~g}$ & $1.11 \mathrm{ab}$ & $0.15 \mathrm{a}$ & $0.91 \mathrm{abc}$ & $0.27 \mathrm{ab}$ & $0.09 \mathrm{a}$ & $0.20 \mathrm{bc}$ & $101 \mathrm{ab}$ & $1013 \mathrm{ab}$ & $41 \mathrm{a}$ & $5.2 \mathrm{ab}$ & $75 \mathrm{a}$ & $142 \mathrm{ab}$ \\
\hline \multicolumn{13}{|l|}{$\mathrm{CR}$} \\
\hline $25 \mathrm{~g}$ & $1.08 \mathrm{ab}$ & $0.13 \mathrm{abc}$ & $0.86 \mathrm{abc}$ & $0.26 \mathrm{ab}$ & $0.08 \mathrm{a}$ & $0.18 \mathrm{bc}$ & $142 \mathrm{ab}$ & $955 \mathrm{ab}$ & $49 a$ & $6.8 \mathrm{ab}$ & $68 \mathrm{a}$ & $166 a b$ \\
\hline $50 \mathrm{~g}$ & $1.07 \mathrm{ab}$ & $0.12 b c$ & $0.85 \mathrm{abc}$ & $0.23 \mathrm{ab}$ & $0.08 \mathrm{a}$ & $0.20 \mathrm{bc}$ & $162 \mathrm{ab}$ & $883 \mathrm{abc}$ & $34 a$ & $6.2 \mathrm{ab}$ & $51 \mathrm{a}$ & $139 \mathrm{ab}$ \\
\hline $75 \mathrm{~g}$ & $1.15 \mathrm{a}$ & $0.15 \mathrm{a}$ & $0.92 \mathrm{ab}$ & $0.20 \mathrm{~b}$ & $0.08 \mathrm{a}$ & $0.15 \mathrm{c}$ & $109 \mathrm{ab}$ & $556 \mathrm{c}$ & $33 a$ & $3.0 \mathrm{~b}$ & $68 \mathrm{a}$ & $95 \mathrm{~b}$ \\
\hline $100 \mathrm{~g}$ & $1.13 \mathrm{a}$ & $0.14 \mathrm{ab}$ & $0.88 \mathrm{abc}$ & $0.22 \mathrm{ab}$ & $0.08 \mathrm{a}$ & $0.21 \mathrm{bc}$ & $138 \mathrm{ab}$ & $909 \mathrm{ab}$ & $33 a$ & $6.2 \mathrm{ab}$ & $37 \mathrm{a}$ & $172 \mathrm{ab}$ \\
\hline \multicolumn{13}{|l|}{ UR } \\
\hline $25 \mathrm{~g}$ & $1.10 \mathrm{ab}$ & $0.12 b c$ & $0.86 \mathrm{abc}$ & $0.26 \mathrm{ab}$ & $0.10 \mathrm{a}$ & $0.23 \mathrm{ab}$ & $107 \mathrm{ab}$ & $1011 \mathrm{ab}$ & $40 a$ & $5.8 \mathrm{ab}$ & $72 a$ & $142 \mathrm{ab}$ \\
\hline $50 \mathrm{~g}$ & $1.14 \mathrm{a}$ & $0.15 \mathrm{a}$ & $0.96 \mathrm{a}$ & $0.21 b$ & $0.09 \mathrm{a}$ & $0.18 b c$ & $94 \mathrm{~b}$ & $681 b c$ & $35 \mathrm{a}$ & $3.8 \mathrm{~b}$ & $58 \mathrm{a}$ & $99 b$ \\
\hline $75 \mathrm{~g}$ & $1.09 \mathrm{ab}$ & $0.15 \mathrm{a}$ & $0.88 \mathrm{abc}$ & $0.28 \mathrm{ab}$ & $0.09 \mathrm{a}$ & $0.22 \mathrm{abc}$ & $138 \mathrm{ab}$ & $814 a b c$ & $48 \mathrm{a}$ & $8.0 \mathrm{ab}$ & $51 \mathrm{a}$ & $163 a b$ \\
\hline $100 \mathrm{~g}$ & $1.04 \mathrm{~b}$ & $0.13 \mathrm{abc}$ & $0.82 \mathrm{bc}$ & $0.27 \mathrm{ab}$ & $0.09 \mathrm{a}$ & $0.22 \mathrm{abc}$ & $155 \mathrm{ab}$ & $872 \mathrm{abc}$ & $44 a$ & $5.4 \mathrm{ab}$ & $61 \mathrm{a}$ & $151 \mathrm{ab}$ \\
\hline \multicolumn{13}{|l|}{$\mathrm{AN}$} \\
\hline $25 \mathrm{~g}$ & $1.03 \mathrm{~b}$ & $0.14 \mathrm{ab}$ & $0.88 \mathrm{abc}$ & $0.30 \mathrm{ab}$ & $0.09 a$ & $0.20 \mathrm{bc}$ & $140 \mathrm{ab}$ & $1001 \mathrm{ab}$ & $45 \mathrm{a}$ & $5.4 \mathrm{ab}$ & $65 \mathrm{a}$ & $157 \mathrm{ab}$ \\
\hline $50 \mathrm{~g}$ & $1.12 \mathrm{ab}$ & $0.13 \mathrm{abc}$ & $0.85 \mathrm{abc}$ & $0.23 \mathrm{ab}$ & $0.08 \mathrm{a}$ & $0.22 \mathrm{abc}$ & $113 a b$ & $969 \mathrm{ab}$ & $39 a$ & $5.0 \mathrm{ab}$ & $67 a$ & $146 a b$ \\
\hline $75 \mathrm{~g}$ & $1.10 \mathrm{ab}$ & $0.14 \mathrm{ab}$ & $0.92 \mathrm{ab}$ & $0.22 \mathrm{ab}$ & $0.08 \mathrm{a}$ & $0.20 \mathrm{bc}$ & $129 \mathrm{ab}$ & $731 \mathrm{abc}$ & $34 \mathrm{a}$ & $5.0 \mathrm{ab}$ & $61 \mathrm{a}$ & $126 \mathrm{ab}$ \\
\hline $100 \mathrm{~g}$ & $1.13 \mathrm{a}$ & $0.15 \mathrm{a}$ & $0.89 \mathrm{abc}$ & $0.26 \mathrm{ab}$ & $0.09 \mathrm{a}$ & $0.24 \mathrm{ab}$ & $138 \mathrm{ab}$ & $964 \mathrm{ab}$ & $40 a$ & $4.6 \mathrm{ab}$ & $74 \mathrm{a}$ & $156 a b$ \\
\hline Control & $0.82 \mathrm{c}$ & $0.10 \mathrm{c}$ & $0.76 \mathrm{c}$ & $0.33 \mathrm{a}$ & $0.09 \mathrm{a}$ & $0.30 \mathrm{a}$ & $238 \mathrm{a}$ & $1194 \mathrm{a}$ & $49 a$ & $9.8 \mathrm{a}$ & $76 \mathrm{a}$ & $196 \mathrm{a}$ \\
\hline
\end{tabular}

${ }^{a}$ Within each element and season, means sharing a letter do not differ significantly at $\alpha=0.05$, and $n=5$ for each combination of formulation and application rate.

0.037), Mn $(P=0.027)$, and $\mathrm{Cu}(P=0.025)$ were influenced by treatment and by season $(P=0.018, P=0.004$, and $P<0.001$, respectively) according to ANOVAR (Table 3). For Fe, the concentration in the control exceeded those in all other treatments during the first season but only that in the $50 \mathrm{~g}$ UR treatment during the fifth season. Foliar Mn was greater in the control than in the $50 \mathrm{~g}$ and $75 \mathrm{~g} \mathrm{CR}$ and UR treatments during the first season with a greater control concentration than those in the $75 \mathrm{~g} \mathrm{CR}$ and $50 \mathrm{~g}$ UR treatments for the fifth season. The LSD test revealed additional disparities for Mn consisting of higher concentrations in the $300 \mathrm{~g} \mathrm{MB}$ and $25 \mathrm{~g}$ AN treatments than in the $50 \mathrm{~g}$ UR treatment during the former and higher ones in all of the MB treatments, the $25 \mathrm{~g}$ and $100 \mathrm{~g} \mathrm{CR}$ treatments, the $25 \mathrm{~g}$ UR treatment, and the $25 \mathrm{~g}, 50 \mathrm{~g}$, and $100 \mathrm{~g}$ AN treatments than that in the $75 \mathrm{~g}$ CR treatment during the latter. Significant disparities in $\mathrm{Cu}$ were limited to a higher concentration in the control than those in the $100 \mathrm{~g}$ and $200 \mathrm{~g} \mathrm{MB}$ and 50 g CR treatments during the first season and those in the $75 \mathrm{~g} \mathrm{CR}$ and $50 \mathrm{~g}$ UR treatments during the fifth season. Except for the 25 UR and AN treatments and the control, Fe concentrations increased from the first to the fifth season, as was the trend for Mn except for the $300 \mathrm{~g} \mathrm{MB}$ and $75 \mathrm{~g} \mathrm{CR}$ treatments. Foliar $\mathrm{Cu}$ concentrations, however, declined from the first to the fifth season within every treatment.

Significant treatment $(P=0.041)$ and season $(P<$ 0.001 ) effects were also revealed for foliar Al by ANOVAR (Table 3). In the first season, a higher concentration in the control than in the $50 \mathrm{~g} \mathrm{CR}$ treatment was indicated by the LSD test, while in the fifth season, the control concentration exceeded those in the $75 \mathrm{CR}$ and $50 \mathrm{~g}$ UR treatments. Foliar Al declined from the first to the fifth season within all treatments.

\section{Discussion}

The magnitude of the disturbance where this study was conducted, and the inhospitable nature of the substrate for plant growth left in its aftermath, necessitated that a technical reclamation approach, entailing the planting of seedlings, rather than spontaneous succession constitute the means by which on-site productivity is restored and off-site perturbations are minimized [35]. As is often the case on such sites, the deficiencies of the substrate as a plant growth medium must be rectified, but if the measure employed inadvertently induces seedling mortality, 
the progression toward a reliable vegetative cover may be summarily precluded. As was made apparent by the complete absence of mortality here, a three-year postplanting delay of fertilization was sufficient to ensure that survival was not compromised when substrate infertility mandated its use, and thus to avoid the aforementioned unpredictable survival responses to amendments administered at planting.

Given that growth enhancement, especially of prolonged duration, is the primary purpose of fertilization, the performance of the individual amendment formulations and application rates from such a perspective was of paramount interest in this study. Using seedling volume as an indicator of overall growth responses and seasons 1 - 5 outcomes as a predictor of their persistence, 75 $\mathrm{g}$ of $\mathrm{CR}$ and $50 \mathrm{~g}$ of UR represented the confluences of formulation and rate providing the most stimulation among the combinations investigated, although in most comparisons they were numerically superior rather than statistically distinguishable from other combinations. Nevertheless, the resin coating of the former and the urea $\mathrm{N}$ source of the latter was apparently not a hindrance to nutrient release sufficient to preclude augmenting critical ion availability in the rooting zone even with surface applications. Comparatively, the MB and AN formulations were less stimulatory insomuch as they failed to induce volume growth in seasons 1 - 5 differing statistically from that of the control regardless of application rate. In fact, MB infrequently produced growth significantly exceeding that of the control irrespective of variable considered and, at that, such instances occurred in seasons $0-1$ exclusively, perhaps suggesting that the transformation of the biosolid $\mathrm{N}$ to a plant available form did not transpire to the degree needed for a more satisfactory growth enhancement despite the compensatory application rates reflecting its relatively low $\mathrm{N}$ content. A somewhat greater stimulation was provided by $\mathrm{AN}$, with instances of relative growth exceeding that of the control occurring in both the height and diameter dimensions during the seasons $0-1$ and $1-5$ periods along with a greater volume response during the former, indicating that the ready solubility of this amendment proved to be less of a shortcoming over the course of the study than that presented by the biosolid origin of MB. It is perhaps noteworthy that in a comparison of the levels of growth stimulation in this study with those of a sapling study of the same species conducted on a similar site [36], the 75 $\mathrm{g} \mathrm{CR}$ and $50 \mathrm{~g}$ UR treatments induced relative seedling growth here that was more than double that by the most advantageous application rates of these two formulations used in the sapling study for the height and diameter dimensions and more than $6 \times$ that for volume over an identical time span, suggesting that surface broadcasting of nutrient amendments is more effective in the seedling stage than during the sapling stage of stand development on harsh sites.

Reliance on foliar analysis for assessments of seedling nutrition necessitates incorporation of reference standards for meaningful interpretation, and those of Jones et al. [37] are best suited for such purposes here. Based on the above reference values, foliar $\mathrm{N}$ and $\mathrm{P}$ were low in all treatments during both the first and fifth posttreatment seasons but were especially so in the latter and in the control treatment. Contrarily, $\mathrm{K}$ was elevated during the first season, especially in fertilized seedlings, before receding to values only marginally so in the fifth season except for that in the control, which was marginally low, while $\mathrm{Ca}$ concentrations were generally comparable to the reference value in all treatments throughout the study. However, like $\mathrm{N}$ and $\mathrm{P}$, foliar Mg was low regardless of treatment in the first season and even more so during the final season. The Jones et al. [37] standards do not include a value for $\mathrm{S}$, but in comparison to the concentration in unfertilized Jeffrey pine seedlings growing on a routine reforestation site [34], all values here were elevated with those in the control especially so.

In light of the above interpretive information regarding foliar N and P, coupled with the low soil levels of these two critical macronutrients, it is reasonable to conclude that enhanced $\mathrm{N}$ and $\mathrm{P}$ nutrition was a substantial contributor to the positive growth responses here of seedlings fertilized with several combinations of amendment formulation and application rate. Fertilization trials with an array of species on multiple surface mine sites have indicated $\mathrm{N}$ and $\mathrm{P}$ nutrition to be an important determinant of growth performance $[9,38,39]$. Perhaps less sure was the contribution of improved $\mathrm{K}$ nutrition to the growth of fertilized seedlings, as soil $\mathrm{K}$ was not deficient, foliar $\mathrm{K}$ was high even in the control initially and the control concentration was only marginally low later, and all MB treatments had more $\mathrm{K}$ than the control during the first season and this formulation contains no source for this nutrient nor did it induce much growth. The higher foliar $\mathrm{Ca}$ and $\mathrm{S}$ concentrations revealed here in the control relative to some of the other treatments are probably indicative of a dilution effect associated with greater biomass production of the latter [40] and were of little consequence in seedling growth, as the levels of these two nutrients were high in the soil and at least adequate in foliage regardless of treatment. Apparently, the low foliar $\mathrm{Mg}$ revealed here was of little consequence as well, as soil $\mathrm{Mg}$ was abundant and given that foliar $\mathrm{Mg}$ was never influenced by treatment, the source of this macronutrient in the CR formulation was nutritionally irrelevant.

Like the macronutrients, most of the micronutrients deviated from the Jones et al. [37] reference standards in at least some portion of the treatments. Foliar Fe was low in fertilized seedlings but high in the control during both 
the first and fifth seasons, although the disparities were somewhat less pronounced in the latter. In contrast, Mn was markedly elevated in all treatments, somewhat more so in the fifth than the first seasons, but was especially so in the control where values were $15.5 \times$ the reference standard initially and $16.1 \times$ that in the final season. However, $\mathrm{Zn}$ concentrations were low in all treatments throughout the study, while those of $\mathrm{Cu}$ in fertilized seedlings were comparable to the reference standard initially while marginally elevated in the control but generally low in the former while marginally high in the latter during the final season. Foliar B was high in all treatments without exception in both the first and fifth seasons. No value for $\mathrm{Al}$ appears in the Jones et al. [37] standards, but compared to that in the aforementioned unfertilized Jeffrey pine seedlings on a routine site [34], none of the values here were elevated.

The high soil levels of all of the micronutrients and of $\mathrm{Al}$ here raises the possibility that phytotoxicity associated with one or more of these elements influenced treatment responses. Perhaps $\mathrm{Fe}$ is a case in point, and if so fertilization functioned in an ameliorative capacity, possibly through an exaggerated form of the aforementioned dilution effect. Although somewhat less prominently than that of $\mathrm{Mn}$ and $\mathrm{Al}, \mathrm{Fe}$ toxicity has been a documented concern in assessing the revegetation potential of a variety of surface mined sites [12,41,42]. Regarding Mn, however, this element may represent the most likely case of any phytotoxicity occurring in this study given the extreme degree to which foliar levels were elevated, and in turn the most likely example of a capacity of fertilization to alleviate it. The universally low foliar $\mathrm{Zn}$ concentrations found here eliminate it from consideration, and treatment influences on these concentrations were entirely absent regardless. The nominal elevation of $\mathrm{Cu}$ in the control treatment only renders the status of this element uncertain concerning a possible phytotoxicity, although it may be noteworthy that concentrations in the $75 \mathrm{~g} \mathrm{CR}$ and $50 \mathrm{~g}$ UR treatments were greatly reduced relative to the control during the final season, and this is also an element that has sometimes been identified as problematic in surface mine revegetation $[13,43]$. With little information available on B toxicity in forest trees [44], it is purely speculative to view the universally high foliar levels found here as evidence of phytotoxicity, but regardless, treatment influences on this element were absent as well. An obvious side note to the above discussion of micronutrients is the irrelevance of these elements as delivered by three of the formulations themselves, ranging from $\mathrm{Fe}$ alone in MB and UR to the extensive array contained in $\mathrm{CR}$, which apparently were of no nutritional consequence whatsoever in this study given that foliar concentrations in fertilized seedlings were frequently lower than those in the control. Despite foliar $\mathrm{Al}$ concentrations that were not elevated according to the only reference value currently available for comparison purposes, the mine site used in this study has been assessed as potentially $\mathrm{Al}$ toxic to vegetation [17], making the low values in the $75 \mathrm{~g} \mathrm{CR}$ and $50 \mathrm{~g}$ UR treatments relative to that in the control during the final season perhaps more notable than they might be perceived otherwise.

\section{Conclusion}

Assessed here was the capacity of four fertilizer formulations applied by broadcasting three years after planting at four rates each to reinvigorate Jeffrey pine seedlings on a sulfurous eastern Sierran surface mine. Regardless of formulation and application rate, fertilization did not impinge on seedling survival. Relative growth measures indicated that a controlled release amendment featuring urea, ammoniacal, and nitrate $\mathrm{N}$ sources and a conventional formulation featuring the former as the near exclusive $\mathrm{N}$ source were the most stimulatory, a water soluble fertilizer with ammoniacal and nitrate $\mathrm{N}$ less so, and an organic amendment relying exclusively on municipal biosolid $\mathrm{N}$ the least stimulatory overall. For the two best formulations, intermediate application rates among those tested rather than the lowest or highest generally produced greater growth responses. Added growth from fertilization probably reflected the augmentation of scarce soil $\mathrm{N}$ and $\mathrm{P}$, although enhanced availability of $\mathrm{K}$ may have also contributed. Reduced concentrations of potentially phytotoxic metallic elements, which were abundant in the soil, associated with several combinations of formulation and application rate may have contributed as well, most notably regarding Mn but possibly including $\mathrm{Fe}, \mathrm{Cu}$, and $\mathrm{Al}$. These findings provide for a more thorough understanding of the potential benefits that fertilization offers in efforts to reforest surface mines and similar adverse sites.

\section{Acknowledgements}

Financial support for this research was provided by the Nevada Agricultural Experiment Station and the McIntireStennis Cooperative Forestry Research Program. Thanks are extended to J. Chacon, R. Fecko, G. Fernandez, W. Frederick, C. McCarthy, and J. Spurlock for their assistance.

\section{REFERENCES}

[1] A. D. Bradshaw and M. J. Chadwick, "The Restoration of Land: The Ecology and Reclamation of Derelict and Degraded Land," University of California Press, Berkeley, 1980.

[2] R. J. Hobbs and D. A. Norton, "Towards a Conceptual Framework for Restoration Ecology," Restoration Eco- 
logy, Vol. 4, No. 2, 1996, pp. 93-110. doi:10.1111/j.1526-100X.1996.tb00112.x

[3] W. G. Vogel, "A Guide for Revegetating Coal Minesoils in the Eastern United States," General Technical Report NE-68, USDA Forest Service Northeastern Forest Experiment Station, Broomall, 1981.

[4] D. Binkley, "Forest Nutrition Management," John Wiley \& Sons, New York, 1986.

[5] R. F. Fisher and D. Binkley, "Ecology and Management of Forest Soils," 3rd Edition, John Wiley \& Sons, New York, 2000

[6] M. M. Czapowskyj, "Establishing Forest on SurfaceMined Land as Related to Fertility and Fertilization," Forest Fertilization Symposium Proceedings, General Technical Report NE-3, USDA Forest Service Northeastern Forest Experiment Station, Upper Darby, 1973, pp. 132139.

[7] R. van den Driessche, "Effects of Nutrients on Stock Performance in the Forest," In: R. van den Driessche, Ed., Mineral Nutrition of Conifer Seedlings, CRC Press, Boca Raton, 1991, pp. 229-260.

[8] R. F. Walker, D. C. West, S. B. McLaughlin and C. C. Amundsen, "Growth, Xylem Pressure Potential, and Nutrient Absorption of Loblolly Pine on a Reclaimed Surface Mine as Affected by an Induced Pisolithus tinctorius Infection," Forest Science, Vol. 35, No. 2, 1989, pp. 569581.

[9] C. N. Casselman, T. R. Fox, J. A. Burger, A. T. Jones and J. M. Galbraith, "Effects of Silvicultural Treatments on Survival and Growth of Trees Planted on Reclaimed Mine Lands in the Appalachians," Forest Ecology and Management, Vol. 223, No. 1-3, 2006, pp. 403-414. doi:10.1016/j.foreco.2005.12.020

[10] D. A. Rook, "Seedling Development and Physiology in Relation to Mineral Nutrition," In: R. van den Driessche, Ed., Mineral Nutrition of Conifer Seedlings, CRC Press, Boca Raton, 1991, pp. 85-111.

[11] R. F. Walker, "Advancing Forest Cover Development on a High-Elevation Sierra Nevada Mine Site with Nutritional Amendments," Restoration Ecology, Vol. 16, No. 3, 2008, pp. 486-494. doi:10.1111/j.1526-100X.2007.00322.x

[12] D. G. Cummins, W. T. Plass and C. E. Gentry, "Chemical and Physical Properties of Spoil Banks in the Eastern Kentucky Coal Fields," Research Paper CS-17, USDA Forest Service Central States Forest Experiment Station, Columbus, 1965.

[13] R. I. Barnhisel and H. F. Massey, "Chemical, Mineralogical and Physical Properties of Eastern Kentucky Acid-Forming Coal Spoil Materials," Soil Science, Vol. 108, No. 5, 1969, pp. 367-372. doi:10.1097/00010694-196911000-00010

[14] W. A. Berg and W. G. Vogel, "Toxicity of Acid Coal Mine Spoils to Plants," In: R. J. Hutnik and G. Davis, Eds., Ecology and Reclamation of Devastated Land, Gordon \& Breach, New York, 1973, pp. 57-68.

[15] K. Hage, "Recultivation in the Lusatian Mining Region: Targets and Prospects," Water, Air and Soil Pollution,
Vol. 91, No. 1-2, 1996, pp. 43-57. doi:10.1007/BF00280922

[16] Z. Strzyszcz, "Recultivation and Landscaping in Areas after Brown-Coal Mining in Middle-East European Countries," Water, Air and Soil Pollution, Vol. 91, No. 1-2, 1996, pp. 145-157. doi:10.1007/BF00280930

[17] R. I. Butterfield and P. T. Tueller, "Revegetation Potential of Acid Mine Wastes in Northeastern California," Reclamation Review, Vol. 3, No. 1, 1980, pp. 21-31.

[18] California Environmental Protection Agency, "Abandoned Mine Lands Preliminary Assessment Handbook," California Environmental Protection Agency, Sacramento, 1998.

[19] R. W. Brown, M. C. Amacher, W. F. Mueggler and J. Kotuby-Amacher, "Reestablishing Natural Succession on Acidic Mine Spoils at High Elevation: Long-Term Ecological Restoration," Research Paper RMRS-RP-41, USDA Forest Service Rocky Mountain Forest and Range Experiment Station, Fort Collins, 2003.

[20] D. A. Mays and G. W. Bengtson, "Lime and Fertilizer Use in Land Reclamation in Humid Regions," In: F. W. Schaller and P. Sutton, Eds., Reclamation of Drastically Disturbed Lands, American Society of Agronomy, Madison, 1978, pp. 307-328.

[21] R. M. Smith and A. A. Sobek, "Physical and Chemical Properties of Overburdens, Spoils, Wastes, and New Soils," In: F. W. Schaller and P. Sutton, Eds., Reclamation of Drastically Disturbed Lands, American Society of Agronomy, Madison, 1978, pp. 149-172.

[22] J. Katzur and M. Haubold-Rosar, "Amelioration and Reforestation of Sulfurous Mine Soils in Lusatia (Eastern Germany)," Water, Air and Soil Pollution, Vol. 91, No. 12, 1996, pp. 17-32. doi:10.1007/BF00280920

[23] R. F. Walker, "Growth and Nutritional Responses of Bareroot Jeffrey Pine on a Sierra Nevada Surface Mine to Minisite Applications of Fertilizer and Lime," New Forests, Vol. 24, No. 3, 2002, pp. 225-238. doi:10.1023/A:1021337321332

[24] R. F. Walker, "Reestablishment of Jeffrey Pine on an Acidic Sierra Nevada Surface Mine: Influence of Fertilizer and Lime Amendments on Early Growth and Nutrition," Journal of Sustainable Forestry, Vol. 15, No. 3, 2002, pp. 1-27. doi:10.1300/J091v15n03 01

[25] R. F. Walker, "Comparison of Organic and Chemical Soil Amendments Used in the Reforestation of a Harsh Sierra Nevada Site," Restoration Ecology, Vol. 11, No. 4, 2003, pp. 466-474. doi:10.1046/j.1526-100X.2003.rec0216.x

[26] D. A. Potter, "Guide to Forested Communities of the Upper Montane in the Central and Southern Sierra Nevada," Technical Publication R5-ECOL-TP-003, USDA Forest Service Pacific Southwest Region, Sonora, 1994.

[27] A. L. Page, R. H. Miller and D. R. Keeney, "Methods of Soil Analysis: Part 2, Chemical and Microbiological Properties," 2nd Edition, American Society of Agronomy, Madison, 1982.

[28] A. Klute, "Methods of Soil Analysis: Part 1, Physical and Mineralogical Methods," 2nd Edition, American Society of Agronomy, Madison, 1986. 
[29] G. H. Schubert and R. S. Adams, "Reforestation Practices for Conifers in California," California Department of Forestry, Sacramento, 1975.

[30] S. L. Tisdale, W. L. Nelson and J. D. Beaton, "Soil Fertility and Fertilizers," 4th Edition, Macmillan Publishing Company, New York, 1985.

[31] R. F. Walker, "Responses of Jeffrey Pine on a Surface Mine Site to Fertilizer and Lime," Restoration Ecology, Vol. 10, No. 2, 2002, pp. 204-212. doi:10.1046/j.1526-100X.2002.00070.x

[32] J. L. Ruehle, D. H. Marx and H. D. Muse, "Calculated Nondestructive Indices of Growth Response for Young Pine Seedlings," Forest Science, Vol. 30, No. 2, 1984, pp. 469-474.

[33] K. Helrich, "Official Methods of Analysis: Volume 1," 15th Edition, Association of Official Analytical Chemists, Arlington, 1990.

[34] R. F. Walker, "Artificial Regeneration of Jeffrey Pine in the Sierra Nevada: Growth, Nutrition, and Water Relations as Influenced by Controlled Release Fertilization and Solar Protection," Journal of Sustainable Forestry, Vol. 9, No. 3-4, 1999, pp. 23-38. doi:10.1300/J091v09n03 02

[35] K. Prach and R. J. Hobbs, "Spontaneous Succession versus Technical Reclamation in the Restoration of Disturbed Sites," Restoration Ecology, Vol. 16, No. 3, pp. 363-366. doi:10.1111/j.1526-100X.2008.00412.x

[36] R. F. Walker, "Nutritional Augmentation of Jeffrey Pine Saplings on a Harsh Sierran Site," Journal of Sustainable Forestry, Vol. 30, No. 4, 2011, pp. 263-283. doi:10.1080/10549811.2010.490107

[37] J. B. Jones Jr., B. Wolf and H. A. Mills, "Plant Analysis
Handbook," Micro-Macro Publishing, Athens, 1991.

[38] D. Heinsdorf, "Development of Forest Stands in the Lusatian Lignite Mining District after Mineral Fertilization Adapted to Site and Tree Species," Water, Air and Soil Pollution, Vol. 91, No. 1-2, 1996, pp. 33-42. doi:10.1007/BF00280921

[39] A. Singh, A. K. Jha and J. S. Singh, "Effect of Nutrient Enrichment on Native Tropical Trees Planted on Singrauli Coalfields, India," Restoration Ecology, Vol. 8, No. 1,2000 , pp. $80-86$. doi:10.1046/j.1526-100x.2000.80011.x

[40] V. R. Timmer, "Interpretation of Seedling Analysis and Visual Symptoms," In: R. van den Driessche, Ed., Mineral Nutrition of Conifer Seedlings, CRC Press, Boca Raton, 1991, pp. 113-134.

[41] J. D. Lawrey, "Trace Metal Accumulation by Plant Species from a Coal Strip-Mining Area in Ohio," Bulletin of the Torrey Botanical Club, Vol. 104, No. 4, 1977, pp. 368375. doi: $10.2307 / 2484782$

[42] W. H. O. Pietsch, "Recolonization and Development of Vegetation on Mine Spoils Following Brown Coal Mining in Lusatia," Water, Air and Soil Pollution, Vol. 91, No. 1-2, 1996, pp. 1-15.

[43] H. F. Massey and R. I. Barnhisel, "Copper, Nickel, and Zinc Released from Acid Coal Mine Spoil Materials of Eastern Kentucky," Soil Science, Vol. 113, No. 3, 1972, pp. 207-212. doi:10.1097/00010694-197203000-00011

[44] R. O. Nable, G. S. Banuelos and J. G. Paull, "Boron Toxicity," Plant and Soil, Vol. 198, No. 1-2, 1997, pp. 181198. doi:10.1023/A:1004272227886 